\title{
LOCAL WISDOM SEBAGAI DASAR DALAM PEMBENTUKAN KARAKTER
}

Firza

email: firza1814@gmail.com

\begin{abstract}
Abstrak
Local Wisdom (kearifan lokal) merupakan salah satu pedoman hidup bermasyarakat. Walaupun sering mengalami perubahan dan perkembangan, tetapi nilai-nilai yang terkandung dalam suatu kearifan lokal tidak mengalami perubahan. Warisan yang ditinggalkan oleh leluhur harus tetap dilestarikan. Salah satu cara terbaik untuk menjaganya dengan mengimplementasikan nilai-nilai melalui pendidikan. Nilai-nilai yang terkandung di dalam local wisdom sangat banyak, tetapi anak tidak akan kasulitan untuk memahami karena selalu dekat dengan situasi konkrit kehidupan sehari-hari. Pembentukan karakter pada anak dimulai dari lingkungan terdekat. Nilai-nilai yang ada dalam kearifan lokal akan menjadi dasar dalam pembentukan karakter siswa. Kesadaran akan local wisdom akan membuat anak menjadi paham tentang kebudayaan daerah mereka dan akan membentuk karakter anak. Pembentukan karakter melalui kearifan lokal akan mudah dipahami anak, sehingga karakter mereka kuat dan akan tetap bertahan dari gempurang arus global saat sekarang.
\end{abstract}

Kata Kunci : Lokal Wisdom, Nilai-Nilai Kearifan Lokal, Karakter, Pendidikan. 


\section{PENDAHULUAN}

Secara historis, jika memperhatikan hakikat kontenya, usia pendidikan karakter sesungguhnya seumur dengan sejarah pendidikan itu sendiri. Hanya saja penggunaan istilahnya yang berbeda. Istilah pendidikan karakter baru muncul pada dekade terakhir di Amerika Serikat, termasuk Indonesia baru menggunakan istilah tersebut dalam beberapa tahun terakhir. Suyata (2011:13) menjelaskan bahwa sepuluh sampai dua puluh tahun yang lalu, istilah pendidikan moral lebih popular di Amerika, sedangkan istilah pendidikan karakter lebih populer di kawasan Asia. Sementara di Inggris lebih menyukai istilah pendidiikan nilai, dan secara khusus di Indonesia telah terpakai pula istilah pendidikan moral pancasila.

Karakter menjadi persoalan yang hangat dibicarakan di negara Indonesia saat ini. Banyaknya para pejabat/birokrat yang terlibat korupsi menjadi suatu tanda bahwa ada sesuatu yang berubah pada manusianya. Konflik antar suku, ras, agama juga terjadi dibeberapa wilayah di Indonesia. Tidak hanya itu, pencurian, pembunuhan dan tawuran antara pelajar juga mewarnai berita di media cetak dan elektronik. Dari hal tersebut terlihat ada suatu permasalah, yakni menurunnya nilai-nilai karakter pada manusianya. Dari persoalan tersebut lahir banyak argumen, salah satu sorotannya adalah dunia pendidikan. Muncul banyak pendapat bahwa pendidikan selama ini hanya memberikan pengatuhan kepada siswa, sementara sikap belum terbentuk secara utuh. Sejak saat itu, perubahan-perubahan terus dilakukan dalam kebijakan pendidik, termasuk yang paling muktahir dilakukan adalah perubahan kurikulum 2013 yang mengutamakan pembentukan karakter pada diri peserta didik.

Melihat dari perubahan kurikulum yang bebrapa kali mengalami perubahan di Indonesia, secara tersirat pembentukan karakter telah ada di dalamnya. Hal ini sebenarnya tidak menjadi suatu perosalan besar, karena hanya penggunaan istilah yang berbeda, sementara harapannya adalah sama yakni merujuk pada pancasila. Sebagaimana dalam falsafah pancasila tujuan pendidikan adalah untuk mewujudkan masyarakat yang berakhlak mulia, bermoral, beretika, berbudaya, dan beradap. Pada saat dahulu hal itu berjalan dengan baik, tetapi beberapa tahun terakhir sepertinya konsep ini mulai mengalami penurunan. Masyaakat yang berakhlak mulia, bermoral, beretika, berbudaya, dan beradap mulai jarang ditemukan. Perkembangan arus globalisasi dan masuknya budaya dari negara lain menjadi salah satu pengaruh dalam pembentukkan karakter manusia Indonesia. Bangsa Indonesia sangat mudah terpengaruh oleh budaya lain yang masuk, tanpa banyak memilah dengan kebiasaan dan kesusuaian dengan hidup mereka. Terutama untuk para generasi muda, pengaruh negara Barat dan Asia (Korea, Jepang, Thailand) sudah sangat melekat pada diri mereka sehingga budaya sendiri mulai luntur dari pengetahuan generasi muda sekarang.

Keragaman budaya yang dimiliki oleh masing-masing daerah di Indonesia menjadi

salah satu aset yang yang harus dipertahankan. Dari masing-masing budaya tersebut pasti memiliki cara dan pola dalam kehidupan, sehinga hal tersebut menjadi suatu kearifan lokal (local wisdom) pada masyarakat tertentu. Seharusnya hal ini yang menjadi landasan dalam 
pembentukan karakter pada manusia Indonesia. Setiap daerah memiliki kerifan lokal tersendiri, yang akan membantu terbentuknya karakter seseorang akan terbentuk mulai dari lingkungan terkecil disekitar mereka. Keluarga dan lingkungan masyarakat menjadi awal dari terbentuknya karakter seseorang. Hal ini terjadi karena seseorang dengan cepat memahami dan meniru sikap yang ada pada lingkungan terdekat, sehingga menjadi suatu kebiasaan dalam kehidupan seharihari.

Karakter merupakan nilai-nilai perilaku manusia yang berhubungan dengan Tuhan Yang Maha Esa, diri sendiri, sesama manusia, lingkungan dan kebangsaan yang terwujud dalam pikiran, sikap, perasaan, perkataan dan perbuatan berdasarkan norma-norma agama, hukum, tata karma, budaya dan adat istiadat. Dari nilai-nilai yang berperilaku tersebut, yang paling mudah dipahami oleh siswa adalah nilai dalam budaya dan adat sistiadat. Hal ini disebabkan karana budaya dan adat istiadat lebih mengedepankan praktek dalam berperilaku, bukan hanya sebatas teori, sehingga siswa lebih akan sangat mudah dipahami oleh siswa. Menyimak kembali ulasan di atas, krisis karakter mulai melanda bangsa Indonesia, akan tetapi hal ini bisa diantisipasi dengan memperkenalkan buadaya daerah. Setiap daerah memiliki kebudayaan lokal yang berbeda dan memiliki ciri khas tersendiri.

Masyarakat Indonesia sepatutnya untuk kembali kepada jati diri melalui pemaknaan kembali dan rekonstruksi nilai-nilai luhur budaya lokal. Dalam konteks tersebut sebagai upaya yang perlu dilakukan adalah menguak substantive kearifan lokal. Sejarah telah menunjukkan bahwa masing-masing etnis dan suku memiliki kearifan lokal tersendiri. Misalnya suku Batak kental dengan keterbukaannya, Jawa identik dengan kehalusan, suku Madura memiliki harga diri yang tinggi dan etnis Cina terkenal denga keuletannya. Tidak hanya sebatas hal tersebut, setiap suku memiliki keakraban dan keramahan terhadap lingkungan yang mengelilingi mereka. Kerarifan lokal tidak muncul secara tiba-tiba, tetapi melaewati berbagai proses yang cukup panjang yang terbukti mengandung kebaikan bagi kehidupan masyarakat. Dalam situasi ini menjadikan kearifan lokal sebagai budaya yang mentradisi serta melekat kuat dalam kehidupan masyarakat. Artinya sampai pada tingkatan tertentu dalam kehidupan ada nilai-nilai yang berakat kuat pada setiap aspek lokalitas. Hal ini yang nantinya akan menjadikan masyarakatnya memiliki karakter yang kuat.

Dari penjelasan yang dijelaskan di atas, rumusan masalah dalam tulisan ini adalah bagaimanakah local wisdom sebagai dasar dalam pembentukan karakter. Penelitian untuk melihat kearifan lokal suatu daerah sebagai basis dalam pembentukan karakter. Selama ini kearifan lokal hanya dilihat sebagai tradisi atau kebiasaan suatu masyarakat dalam melaksanakan kehidupan. Melihat lebih dalam lagi, bahwa di dalam kehidupan tersebut ada nilai-nilai yang telah mendasar dalam kebiasaan sehari-hari. Sehingga secara tidak sadar bahwa karakter dari suatu masyarakat telah terbentuk.

Aristoteles mendefenisikan karakter yang baik sebagai kehidupan dengan melakukan tindakan-tindakan yang benar sehubungan dengan diri seseorang dan orang lain. Sementara Lickona (2015:82) menyebutkan bahwa ada tiga bagian yang saling berhubungan dalam suatu karakter, yaitu pengetahuan moral, perasaan moral dan perilaku moral. Dari pandangan 
tersebut dapat disimpulakan bahwa karakter berkaitan erat dengan tindakan yang baik. Artinya dalam melakukan tindakan harus ada keseimbangan antara pikiran dan perasaan, rohani dan jasmani sehingga akan membentuk keharmonisan dalam diri seseorang. Mewujudkan karakter yang baik tentu bukan merupakan persoalan yang mudah. Pendidikan merupakan menjadi tempat yang tepat dalam melakukan pendidikan karakter. Sehingga dibeberapa negara melaksanakan pendidikan karakter dan ada juga yang menyebutnya sebagai pendidikan nilai.

Pada bagian awal tulisan bahwa kearifan lokal suatu daerah memiliki ciri yang unik. Fitri (2012:2) kerifan lokal merupakan proses yang sangat lama dan kemudian menjadi sebuah acuan filosofis dan pegangan hidup masyarat. Namun bukan berarti itu adalah sebuah dogma yang tidak bisa berubah, karena tidak ada yang kekal di dunia ini kecuali perubahan itu sendiri. Kearifan lokal perlu dilihat sebagai suatu nilai luhur (lofty value), tidak hanya memandang banar atau salah, tetapi jauh lebih penting adalah kebaikannya. Local wisdom merupakan suatu kebiasaan baik yang dilakukan oleh masyarakat dalam kehidupannya. Kebiasaan baik tersebut tidak hanya berupa perbuatan, bisa dalam bentuk sastra, trasisi religious, kaum bijaksana dan masih banyak yang lain lagi.

Harapannya dari tulisan ini mampu memberikan manfaat kepada masyarakat khususnya pada jenjang sekolah, bahwa dalam kearifan lokal yang mereka miliki mengandung nilai-nilai karakter yang kuat. Dengan memahami nilai-nilai karakter yang ada pada masingmasing daerah mereka, harapannya setiap masyarakat mampu mengambil nilai-nilai yang ada di dalam kearifan lokal mereka, sehingga karakter yang kuat akan terbentuk. Pendidikan karakter tidak hanya dibentuk di sekolah, tetapi akan sangat efektif jika dimulai dari lingkungan terdekat mereka dan dengan kebiasaan yang sudah mereka kenal dengan baik.

\section{METODE}

Metode penelitian menggunakan metode kualitatif, proses pengumpulan data melalui wawancara. Penelitian dilakukan dengan menyakan kepada siswa tetang kearifan lokal di sekitar mereka, lalu mereka diminta untuk mengambil nilai-nilai yang ada di dalamnya. Penelitian di laksanakan pada SMAN 4 Kerinci, provinsi Jambi. Analisis data menggunakan komponen analisis data Milles and Hubermans (1984:20) pengumpulan data, resuksi data, sajian data dan verifikasi/kesimpulan. Data yang telah di ambil dari siswa di olah kemudian diambil kesimpulan.

\section{HASIL DAN PEMBAHASAN}

Masalah karakter masih menjadi persolaan yang terus diperbincaangkan dalam dunia pendidikan. Termasuk dalam perbaikan kurikulumnya yang dianggap masih kurang mengedepankan tentang pembentukan karakter. Hadirnya kurikulum 2013 memberikan warna baru dalam dunia pendidikan, kognitif tidak menjadi prioritas utama, tetapi lebih menegaskan

pada pembentukan karakter. Jika melihat kembali pada kurikulum yang terdahulu, pendidikan karakter bukan merupakan suatu hal yang asing dalam dunia pendidikan Indonesia. Ki Hajar 
Dewantara pernah menyatakan bahwa pendidikan merupakan upaya menumbuhkan budi pekerti (karakter), pikiran dan tubuh anak, agar anak dapat tumbuh dengan sempurna. Dengan demikian pendidikan karakter merupakan bagian integral yang sangat penting dalam pendidikan (Muclas, 2012:33) sehingga tidak boleh dipisahkan dalam isi pendidikan.

Proses pendidikan akan cepat dipahami dan dimengerti dengan memberikan pembelajaran mulai dari lingkungan terdekat, baik keluarga dan lingkungan sekitar. Mempelajari tentang lingkungan sekitar akan banyak memberikan keuntungan, salah satunya adalah memberikan kemudahan pada siswa dalam memahami tentang konsep budaya setempat. Kearifan lokal di sekitar siswa menjadi salah satu bagian yang dekat dengan siswa dan bukan merupakan suatu hal yang baru dalam kehidupan mereka. Banyak hal yang dapat diambil dari kearifan lokal untuk pembelajaran, seperti resolusi konflik yaitu bagaimana cara suatu daerah menyelesaikan suatu masalah. Resolusi konflik antara satu daerah dengan wilayah lain pasti akan berbeda. Tetapi tujuan dari penyelesaian masalah tetap sama, yaitu mencari mewujudkan perdamaian.

Jawa memiliki Wayang yang menceritakan berbagai peristiwa dan digunakan untuk menyampaikan amanah kepada masyarakat. Masyarakat Lampung memiliki kain Kapis, yang gunanya tidak hanya sebatas seutas kain, akan tetapi dalam kain Tapis memiliki nilai-nilai. Seperti di Tapis Pucuk Rebung, mengandung nilai hubungan seseorang baik sesama manusia, dengan alam dan kepada Tuhan. Masyarakat Flores memiliki upacara adat Reba, dalam upacara ini nilai yang harus diambil adalah bahwa ada keinginan untuk menjalani hidup yang lebih baik di tahun baru. Semua kearifan lokal yang disebutkan ini memiliki nilai-nilai, jika hal ini diambil dan diaplikasikan dalam kehidupan sehari-hari, maka karakter suatu masyarakatnya akan terbentuk dan kuat.

Resolusi Konflik merupakan suatu kearifan lokal yang saat sekarang ini tidak banyak digunakan oleh masyarakatnya sendiri. Orang lebih cenderung menggunakan pengadilan dalam menyelesaikan masalah. Tidak menyangkal bahwa menggunakan jalar hukum tidak baik, akan tetapi kurang tetap jika perkaranya masih bisa di selesaikan dengan kearifan lokal di daerah setempat. Di dalam resolusi konflik di berbagai daerah tidak melepaskan aspek kemanusian. Lainnya halnya dengan jalur hukum yang ditempuh, pasti akan ada kalah dan menangnya. Sebagaimana dalam pepatah Minang menyebutkan menang jadi baro kalah jadi $a b u$ artinya kedua yang terlibat di dalam kasus tidak ada yang memperoleh kemengan. Semua perilaku negatif masyarakat yang terjadi dikalangan pelajar dan masyarakat maupun kalangan lainnya, jelas menunjukkan kerapuhan karakter yang cukup parah yang salah satunya disebabkan oleh tidak optimalnya pengembanngan pendidikan karakter di lembaga pendidikan. Pelaksanaan pendidikan karakter harus dipikul oleh semua pihak, termasuk kepala sekolah, para guru, staf tata usaha, tukang sapu, penjaga kantin dan yang terutama lagi orang tua di rumah.

Dari yang dijelaskan di atas, semuanya temasuk kearifan lokal, dan setiap daerah pasti memiliki kaerifan lokal yang berbeda. Sesuai dengan tema dari penelitian ini bahwa local wisdom sebagai dasar dalam pembentukan karakter, artinya semua bentuk kearifan lokal bisa 
sebagai dasar untuk membentuk karakter masyarakatnya. Persoalan yang sering dikeluhkan adalah bagaimana menyadarkan masyarakatnya tentang kearifan lokal, sehingga nilai-nilai yang ada bisa tersampaikan dan akan membentuk karakter dari masyarakatnya. Sehingga tidak merasa ragu dengan ancaman dari budaya asing yang masuk di tengah arus globalisasi saat sekarang ini.

Salah satu cara yang tepat untuk menyampaikan kearifan lokal melalui pendidikan. Sehingga local wisdom bisa tetap terjaga eksistensinya dan nilai-nilai yang terkandung di dalam budaya lokal bisa diimplikasikan dalam kehidupan sehari-hari, dengan demikian karakter dari masyarakat akan terbentuk. Dalam penelitian ini, lokal wisdom yang dipakai adalah tentang resolusi konflik. Setiap daerah memilik cara/metode tersendiri dalam menyelesaikan konflik. Masyarakat Ambon memiliki mekanisme pela, masyarakat Dayak di Kalimantan Barat memiliki basaru sumangat, masyarakat di NTT memiliki ndempa, dan masyarakat Aceh memiliki tepung tawar dan masyarakat Kerinci (Jambi) menyelesaikan konflik dengan mendawah. Berbagai lembaga mekanisme resolusi konflik yang tersebut hadir dan terbangun melalui konteks sosio-historis yang berbeda juga. Walaupun demikian memiliki fungsi mengintegrasikan masyarakat dalam sistem sosial yang damai (Susan, 2012:13-14).

Dalam resolusi konflik tersebut ada nilai-nilai yang harus diambil serta digunakan dalam kehidupan sehari-hari. Adapun nilai-nilai yang bisa diteladani dari mendawah adalah kebersamaan, saling menghormati, religious/keagamaan, komunikatif, jujur, kerja keras dan toleransi. Nilai-nilai tersebut yang seharusnya tertanam dalam diri anak, dan mereka lakukan dalam kehidupan sehari-hari. Jika hal ini telah berjalan dengan baik, maka karakter dari masyarakatnya akan terbentuk dan menjadi kuat. Hal yang sama juga berlaku bagi seluruh asfek local wisdom. Tidak hanya sebatas konsep kebudayaan, tokoh, peristiwa lokal, dan kebiasaan dalam kehidupan sehari-hari yang mendukung bisa dijadikan sebagai dasar dalam pembentukan karakter. Dalam konsep ini, pendidikan menjadi tempat yang tepat dalam untuk menanamkan nilai-nilai lokal kepada anak. Prayitno dan Manullang (2011) mengatakan bahwa "The end of education is character", sehingga bentuk terakhir dari pandidikan akan melahirkan manusia yang tidak hanya kuat dalam ranah kognitif semata, akan tetapi memiliki karakter yang kuat.

Penanaman nilai kearifan lokal bisa dilakukan dengan pendekatan pembelajaran, model, metode dan media pembelajaran. Dalam beberapa waktu terakhir pendidikan karakter menjadi wacana yang serius, akan tetapi sebagian kelompok lupa akan peran dari local wisdom. Hal ini perlu ditegaskan karena untuk membentuk karekter melalui pandidikan yang saat sekarang menggunakan istilah pendidikan karakter merupakan tanggung jawab bersama bagi semua pendidik, baik di rumah maupun di sekolah. Pendidikan karakter harus dimulai dari pendidik itu sendiri. Pendidikan karakter tidak akan mendapatkan hasil yang baik jika hanya sebatas pembelajaran, tetapi harus dipraktikkan dalam perbuatan sehari-hari. Dari penelitian yang dilakukan di SMAN 4 Kerinci, penanaman nilai tentang resolusi konflik dilakukan melalui model pembelajaran. Hasil yang ditemukan, siswa lebih cepat memahami nilai-nilai lokal yang diberikan. 
Hasil temuan tersebut menunjukkan bahwa menggunakan kearifan lokal dalam memberikan pembelajaran akan sangat mudah dipahami oleh siswa. Nilai-nilai dari persitiwa, tokoh dan bukti otentik masih mudah dijangkau oleh siswa, sehingga secara tidak langsung mereka telah mampu membentuk suatu sudut pandang baru pada pemikirannya. Karakter dimaknai sebagai cara berpikir dan berprilaku yang khas tiap individu untuk hidup dan bekerja sama, baik dalam lingkungan keluarga, masyarakat bangsa dan negara. Alasan kearifan lokal menjadi salah satu dasar dalam pembentukan karakter adalah karena anak akan mudah memahami dan belajar dari lingkungan terdekat. Termasuk dalam tingkatan umur, juga menjadi sisi lain dari pembentukan karakter tersebut. Misalnya setelah melewati tahap anakanak, seseorang memiliki karakter, cara yang dapat diramalkan bahwa karakter seseorang berkaitan dengan perilaku yang ada di sekitar dirinya (Kevin Ryan, 1999:5).

Tantangan sekarang dan ke depan adalah bagaimana kita mampu menempatkan pendidikan karakter sebagai sesuatu kekuatan bangsa. Oleh karena itu kebijakan dan implementasi pendidikan yang berbasis karakter di sekolah menjadi sangat penting dan strategis dalam rangka membangun bangsa ini. Kearifan lokal harus berfungsi sebagai salah satu sumber nilai-nilai yang luhur yang harus diambil. Local wisdom bisa menjadi sumur yang tak kunjung kering di musim kemarau panjang, nilai-nilai kebijaksanaan bagi perwujudan citacita bangsa yang seimbang, baik secara lahiriah maupun batiniah. Di samping berfungsi sebagai penyaring bagi nilai-nilai berasal dari luar, kearifan lokal dapat juga digunakan untuk meredam gejolak-gejolak yang bersifat intern.

Diberbagai negara juga telah mengembangkan pendidikan karakter, yang di dalamnya memiliki esensi dan makna yang sama dengan pendidikan moral dan pendidikan akhlak. Tujuannya adalah membentuk pribadi anak, supaya menjadi manusia yang baik, warga masyarakat dan warga negara yang baik. Pendidikan karakter dalam konteks pendidikan di Indonesia adalah pendidikan nilai, yakni pendidikan nilai-nilai luhur yang bersumber dari budaya bangsa Indonesia sendiri, dalam rangka membina kepribadian generasi muda. Pendidikan karakter adalah usahan menanamkan kebiasaan-kebiasaan yang baik (habituation) sehingga peserta didik mampu bersikap dan bertindakn berdasarkan nilai-nilia yang telah menjadi kepribadiannya. Nilai-nilai tersebut harus ditumbuhkan dan dikembangkan dari peserta didik sehingga akan menjadi budaya sekolah (school culture) Pendidikan karakter menurut Thomas Lickona (1991) untuk membentuk kepribadian seseorang melalui pendidikan budi pekerti, yang hasilnya terlihat dalam tidakan nyata seseorang, yaitu tingkah laku yang baik, jujur, bertanggung jawab, menghormati hak oranag lain, kerja keras dan sebagainya.

\section{PENUTUP}

Kearifan lokal merupakan merupakan ciri khas pada masing-masing daerah. Banyak nilai-nilai budaya lokal yang bisa diambil dan masih tetap relevan dalam kehidupan seharihari. Dari nilai-nilai tersebut yang telah terbiasa dilakukan oleh masyarakat akan menjadi identitas dari budaya setempat. Karakter seseorang akan terbentuk dari lingkungan terdekat, local wisdom sebagai salah satu warisan yang mengandung banyak nilai-nilai yang akan 
membentuk karakter yang kuat. Nilai-nilai tersebut akan lebih efektif diterapkan melalui pendidikan. Sehingga pendidikan akan melahirkan generasi yang memiliki pemikirian dan karakter yang kaut. Harapannya, kearifan lokal tidak hanya sebatas pengetahuan lokal, tetapi karakter dari masyarakat bisa berubah menjadi baik setelah memahami local wisdom mereka. Secara singkat dapat dikatakan bahwa kearifan lokal suatu daerah memiliki nilai-nilai yang akan membentuk karakter dari masyarakatnya sendiri dan akan menjadi suatu pedoman dalam kehidupan sehari-hari di masyarakat.

\section{Daftar Pustaka}

Julia, Siti. Implementasi Pendidikan Karakter dalam Pembelajaran. Dinamika Ilmu Vol 14 No 2 Desember 2014.

Nyoman, K.R. 2014. Peranan Karya Sastra, Seni dan Budaya Dalam Pendiidkan Karakter. Yogyakarta: Pustaka Pelajar.

Ryan, Kevin dan Karen E. Bohlin. 1999. Building Character in School:Practical Ways to Bring Moral Instruction to Life. San Frasisco:JOSSEY-BASS A Wiley Imprint.

Samani, Muchlas, dan Hariyanto. 2012. Konsep dan Pendidikan Karakter. Bandung:Remaja Roesdakarya.

Susan, Novri. 2012. Negara GagalMengelola Konflik: Demokrasi dan Tata Kelola Konflik di Indonesia. Yogyakarta: Kopi Pesona Sambisari dengan Pustaka Pelajar

Prayitno \& Belferik Manullang. 2011. Pendidikan Karakter dalam Pembangunan Bangsa. Jakarta: Grasindo.

Sudrajat, Ajat. Mengapa Pendidikan Karakter? Jurnal Pendidikan Karakter, Tahun I Nomor 1 Oktober 2011.

Suyata. 2011. Pendidikan Karakter dalam Perspektif Teori dan Praktik. Yogyakarta: UNY Press.

Thomas Lickona. 1991. Educating For Character: How Our School Can Teach Respect and Rresponsibility. New York: Bantam Books. 